\title{
Formulation and Optimization of Albumin Microspheres for Controlled Delivery of Gene
}

\author{
Suresh S*, Dhara C and Malay C \\ Head, Shree H.N.Shukla Institute of Pharmaceutical Education \& Research-Rajkot \\ B/H Lalpari Lake, Marketing Yard (Bhichri), Rajkot-360005, Gujarat (India).
}

Received: 12 Oct 2020 / Accepted: 6 Nov 2020/ Published online: 01 Jan 2021

*Corresponding Author Email: dharachavda.hns@gmail.com

\begin{abstract}
In this study, albumin microsphere was formulated for microencapsulation of pBR322 plasmid vector which is believed to be a good vehicle of gene. Controlled release system using biocompatible or biodegradable polymers offer many advantages over conventional gene delivery approaches. The pBR322 plasmid loaded microsphere for targeted gene delivery of tumor was prepared by solvent evaporation technique. Albumin was derived from natural biological source (Biopolymer), Biodegradable, as well as well absorbed in tumor tissue. So, Albumin was selected polymer of dosage forms. We formulated and optimized concentration of albumin as well as DNA which will carry and deliver maximum amount of DNA in control manner. Three different concentration of Albumin with three different concentration of DNA were prepared and evaluated for DNA carrying and delivering efficacy. In future, this formulation may play huge role for huge gene delivery successfully to a tumor tissue with great safety.
\end{abstract}

\section{Keywords}

Albumin, Microsphere, Plasmid, Particle size, Solvent evaporation method

$$
* * * * *
$$

\section{INTRODUCTION}

A normal gene may be inserted into a nonspecific location within the genome to replace a nonfunctional gene. This approach is most common. An abnormal gene could be swapped for a normal gene through homologous recombination. The abnormal gene could be repaired through selective reverse mutation, which returns the gene to its normal function. The microspheres of albumin are being widely used for the targeted gene delivery to the tumour cells. Controlled release systems using biodegradable polymers offer may advantages over conventional gene delivery approaches. We have characterized systems for controlled delivery of DNA from implantable polymer matrices and injectable microspheres. Particles within the size range of 1$1000 \mu \mathrm{m}$ are called microspheres. Microspheres are MATERIALS AND METHOD made of polymeric, waxy, or other protective materials. If the polymer used to prepare microspheres is biodegradable, then the microspheres are known as Biodegradable microspheres.

The albumin natural protein. The particulate or the colloidal form of albumin is considered as the potential carrier of drug/proteins for either their site -specific localization or their local application into anatomical discrete site. much of earlier use of serum albumin microsphere was limited to the diagnosis purpose as the microsphere of differentially at selected sites to facilitate the imaging. Now because of selected uptake of protein carrier by tumour cells, the microspheres of albumin are being widely used for the targeted drug delivery to the tumour cells. ${ }^{[1,2]}$ 
Agarose gel electrophoresis ${ }^{[3]}$ Materials

\begin{tabular}{ll}
\hline Reagent & Company name \\
\hline 1\% Agarose & GeNei,Banglore \\
Ethedium bromide & Himedia lab.pvt.Itd \\
Bromophenol blue & Himedia lab.pvt.Itd \\
Plasmid DNA & Himedia lab.pvt.Itd \\
TAE buffer & GeNei,Banglore \\
\hline
\end{tabular}

\section{METHOD:}

An adequate volume of electrophoresis buffer TAE was Prepared, and the electrophoresis tank was filled. Agarose gel (1\%) was prepared in TAE buffer by Melting the Agarose in a microwave oven and it was swirled to ensure even mixing. Ethidium bromide solution was added to the electrophoresis buffer to a final concentration of $0.5 \mu \mathrm{g} / \mathrm{ml}$ to facilitate visualization of DNA fragments during the run. Melted Agarose cooled to $55^{\circ} \mathrm{C}$ in a water bath before pouring onto the gel platform. Melted Agarose was Poured to platform to make its thickness 0.5 to $1 \mathrm{~cm}$ and comb was inserted, Gel was allowed to get solidify. After the gel has hardened, remove the tape from the open ends of the gel platform and the gel comb was withdrawal. The gel casting platform containing the set gel was placed in the electrophoresis tank. Electrophoresis buffer was added just sufficient to cover the gel to a depth of about $1 \mathrm{~mm}$. DNA samples was prepared and $15 \mu \mathrm{l}$ volume of sample DNA and $5 \mu$ of $10 \times$ loading buffer by loaded into the wells with a micropipette. DNA molecular weight markers was added with sample. The DNA was kept at cathode so it can move toward anode. The voltage was set typically 1 to $10 \mathrm{~V} / \mathrm{cm}$ of gel, When the bromphenol blue dye from the loading buffer had migrated a distance judged sufficient for separation of the DNA fragments the power supply was off. The separation of DNA was watched under the UV lamp.

DNA elution:

The following method has been developed to purify DNA from agarose gel. After electrophoresis of DNA in an agarose gel, the DNA fragment to be recovered was excised out of gel with a scalpel. In order to minimize damage to the DNA sample, we used longwave UV light for the shortest time practical. A DNA standard was also run in the gel to estimate the size and the concentration of the DNA fragment to be recovered. The excised gel was placed in the middle of a small parafilm piece and the parafilm was over the gel piece. Using the Petri plate, or thumb, the gel piece was pressed between the parafilm. Upon squeezing, the DNA inside of the gel gets extruded along with the buffer (forming 2-3 droplets). These droplets were then collected with a pipette. After diluting to a suitable volume, the DNA was then purified by conventional phenol: chloroform extraction method. ${ }^{[4]}$

\section{DNA Purification and Quantification:}

Sample purity will be evaluated by also measuring absorbance at $280 \mathrm{~nm}$. Pure dsDNA should give a $A_{260}: A_{280}$ ratio of 1.8 ; ratios significantly less than this indicates the presence of contaminants (especially proteins) which raise the A280. For dsDNA, an optical density (OD) of 1 indicates a concentration of about $50 \mu \mathrm{g} / \mathrm{mL}(50 \mathrm{ng} / \mu \mathrm{L})$.

Concentration of DNA $(\mu \mathrm{g} / \mathrm{ml})=$ Absorption at 260 $\mathrm{nm} X$ dilution factor $X 50$

Procedure:

Take $10 \mu \mathrm{L}$ of sample DNA.

1. Add $490 \mu \mathrm{L}$ of TE buffer ( $\mathrm{T}=\mathrm{Tris}-\mathrm{HCl} 10 \mathrm{mM}$; $\mathrm{E}=$ EDTA, $\mathrm{pH}$ 8; commonly used buffer for storing or diluting DNA). Mix well by pipetting.

2. Carefully clean a quartz cuvette with $95 \%$ ethanol: dry. Transfer your sample to this cuvette.

3. (Instructor will have turned on the spectrophotometer 30 minutes ahead to allow UV bulb to warm up). Set spectrophotometer absorbance to $260 \mathrm{~nm}$ or engage the program for measuring [dsDNA].

4. Insert a cuvette blank (filled with $500 \mu \mathrm{LTE}$ ) and zero the machine at $260 \mathrm{~nm}$.

5. Insert your sample cuvette and read absorbance at $260 \mathrm{~nm}$.

\{Spectrophotometer should already be programmed to perform steps 7,8 , and 9$\}$

6. Change the wavelength to $280 \mathrm{~nm}$ and read the absorbance again.

7. Calculate dsDNA concentration:

8. A260 $\times$ dilution $\times 50 \mu \mathrm{g} / \mathrm{mL}$

9. Calculate $A_{260}: A_{280}$ ratio to evaluate sample purity. ${ }^{[4]}$ 
Preparation of Microspheres Materials

\begin{tabular}{lll}
\hline Sr.no & Reagent & Company name \\
\hline 1 & Egg albumin & Loba chem \\
2 & Tween-80 & S.D.Fine Chemical lab \\
3 & Hydrochloride & Merck Specialities Ltd \\
4 & Cotton seed oil & Kaneriya oil industry pvt Itd \\
5 & Diethyl ether & Loba chem \\
\hline
\end{tabular}

$0.5 \mathrm{ml}$ of $10 \%$ aqueous albumin solution containing $0.02 \% \mathrm{w} / \mathrm{v}$ of plasmid DNA(PBR322) was added drop wise using a 22-gauge hypodermic needle to $20 \mathrm{~mL}$ of cottonseed oil in a beaker of $100 \mathrm{~mL}$ capacity at room temperature. After the addition was made, a magnetic stirrer was stirred at the highest possible speed for 10 minutes. The water/oil emulsion thus obtained was added drop wise to hot cottonseed oil $(20 \mathrm{~mL})$ maintained at $90^{\circ} \mathrm{C}$ with simultaneous stirring for one of the 15 minutes on a magnetic stirrer, keeping stirring speed at an intermediate level. Later, the suspension containing microspheres and oil was left for 24 hours at room temperature. Supernatant oil was removed by decantation, and microspheres were washed with diethyl ether 3 times. After the third wash, microspheres were suspended in $5 \mathrm{~mL}$ of diethyl ether and were stored at $4^{\circ} \mathrm{C}$. Nine batches were prepared. ${ }^{[1,5,6]}$

\section{EVALUATION PARAMETERS}

\section{Particle size and shape:}

Particle size analysis was performed by optical microscopy using a compound microscope. A small volume of ethereal suspension of microspheres was taken on a clean slide and was allowed to air-dry. The slide containing the dry film of albumin microspheres was mounted on the stage of the microscope and a size of at least 100 particles was measured using a calibrated ocular micrometre. This process was repeated for each batch prepared. Particle size distribution was determined by plotting a percentage frequency polygon using the data obtained during particle size determination. ${ }^{[1,6]}$

\section{DNA entrapment efficiency: ${ }^{[1,7,8,9]}$}

\section{Theoretical yield}

- that is, the amount of DNA that should be present in microspheres-was determined by calculation assuming that all the DNA present in the albumin solution used gets entrapped in microspheres and no loss occurs because of partitioning of DNA into oil phase, washing by diethyl ether, or squeezing due to heat-induced shrinking.

\section{Practical yield}

- that is, the amount of DNA that is actually present in microspheres-was determined by the following method: $10 \mathrm{~mL}$ of ethereal suspension of albumin microspheres was taken in a previously weighed $10-\mathrm{mL}$ volumetric flask. It was kept at $40^{\circ} \mathrm{C}$ for 1 hour to remove diethyl ether completely. The volumetric flask was again weighed, and the weight of the microspheres was obtained. Enough $5 \% \mathrm{v} / \mathrm{v} \mathrm{HCl}$ in $95 \%$ ethanol was added to make the volume $10 \mathrm{~mL}$. The solution was left for 24 hours at room temperature. The supernatant was collected by centrifugation, and the DNA content in the supernatant was determined spectrophotometrically at $260 \mathrm{~nm}$.

\section{In-Vitro DNA release study}

- Instrument: Dissolution apparatus (Elecrolab pvt Itd)

- Dissolution medium: phosphate buffer $(\mathrm{pH}$ 7.4) containing $2 \% \mathrm{w} / \mathrm{w}$ Tween -80

- Temperature: $37 \pm 1^{\circ} \mathrm{C}$

- Sampling: at every 20 hours up to 100 hours.

- Centrifuged: at $5000 \mathrm{rpm}$.

- Analysis: suitably diluted and analyzed spectrophotometrically at $260 \mathrm{~nm}$.

- In-vitro study: Procedure: -

- DNA release from the microspheres was determined using phosphate buffer ( $\mathrm{pH} 7.4)$ containing $2 \% \mathrm{w} / \mathrm{w}$ Tween-80 as the release medium. A weighed amount of microspheres, equivalent to $0.1 \mu \mathrm{g}$ of DNA, were suspended in $50 \mathrm{~mL}$ of the dissolution medium in 100-mL glass vials and stirred on a magnetic stirrer at $50 \mathrm{rpm}$ in a thermostatic bath at $37 \mathrm{C}$.

- Two-milliliter samples were withdrawn at appropriate time intervals and centrifuged at $5000 \mathrm{rpm}$. Supernatants were diluted suitably, and absorbance of the resulting solution was measured at $260 \mathrm{~nm}$ using the dissolution medium as blank. The residue was redispersed in $2 \mathrm{~mL}$ of the fresh dissolution medium and replaced back into the vial. ${ }^{[6,10]}$ 
RESULTS AND DISCUSSION

DNA isolation from $E$. coli pBR322

\begin{tabular}{|c|c|c|}
\hline Absorbance at $260 \mathrm{~nm}\left(\mathrm{~A}_{1}\right)$ & Absorbance at $280 \mathrm{~nm}\left(\mathrm{~A}_{2}\right)$ & $A_{1} / A_{2}$ \\
\hline 1.7 & 1.01 & 1.68 \\
\hline
\end{tabular}

\section{Purification ${ }^{[9,10,11]}$}

If ratio is less than 1.6 RNA is present and if ratio is grater, then 1.8 protein is present.

\section{Quantification}

Concentration $=$ Absorption at $260 \mathrm{~nm} \times 50$

There for concentration of DNA $=1.7 \times 50=85 \mu \mathrm{g} / \mathrm{ml}$.

DNA is present.
R1-Referance plasmid DNA of pUC18.

R2-Referance plasmid DNA of pBR322.

S1 to S5-sample plasmid DNA of pBR322.

The photograph shows spot of sample R2 and S1 to $\mathrm{S} 5$ in same distance of $4.36 \mathrm{~Kb}$ that indicates our sample is plasmid DNA of pBR322.

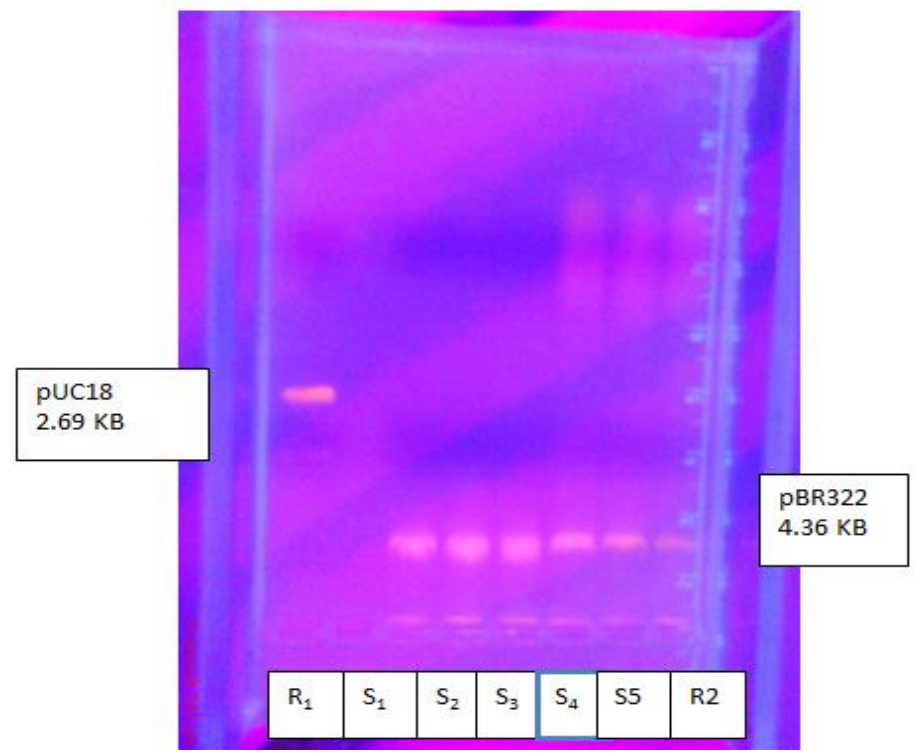

DNA Elution ${ }^{[12,13]}$

Fig. 1: Agarose Gel Electrophoresis

Purification

\begin{tabular}{|l|l|l|}
\hline Absorbance at $\mathbf{2 6 0} \mathbf{n m}\left(\mathbf{A}_{1}\right)$ & Absorbance at $\mathbf{2 8 0} \mathbf{n m}\left(\mathbf{A}_{2}\right)$ & $A_{1} / A_{2}$ \\
\hline 5 & 2.9 & 1.7 \\
\hline
\end{tabular}

Ratios indicate the DNA sample is pure.

\section{Quantification.}

Concentration $=\mathrm{OD} \times$ dilution factor.

There for concentration of DNA $=5 \times 50=250 \mu \mathrm{g} / \mathrm{ml}$ $800 \mu \mathrm{l}$ DNA is diluted in $1000 \mu \mathrm{l}$ TE buffer.

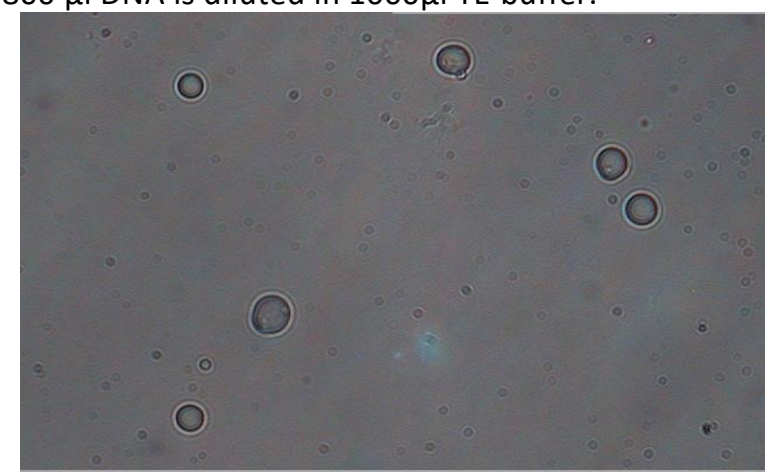

Fig. 2: Albumin microsphere as a placebo $100 \mathrm{X}$ (Albumin Conc. $=10 \% \mathrm{w} / \mathrm{v}$ )
Then OD measured is 4

There for concentration of DNA=4×50 =200 $\mu \mathrm{g} / \mathrm{ml}$

Albumin microsphere:

Albumin microsphere as a placebo

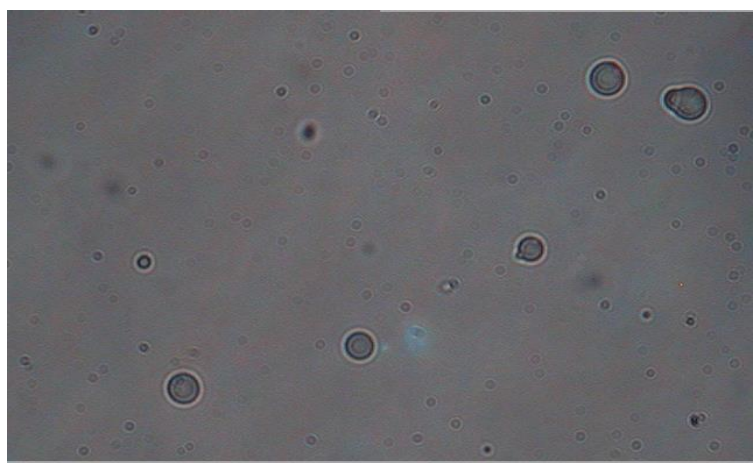

Fig. 3: pBR322 Plasmid loaded Albumin microsphere 100X (Albumin Conc. $=10 \% \mathrm{w} / \mathrm{v}$ and DNA Conc. $=$ $0.02 \% \mathrm{w} / \mathrm{v}$ ) 


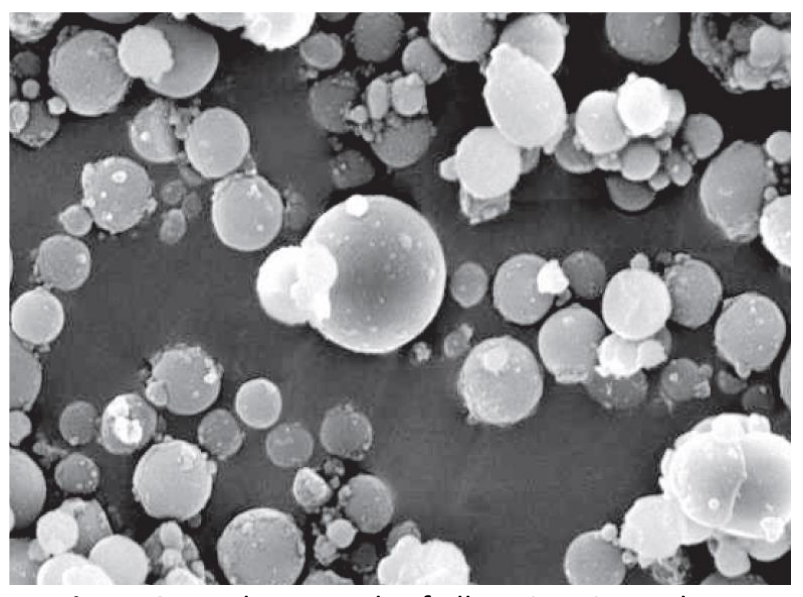

Fig. 4: SEM photograph of albumin microsphere

Effect of albumin concentration and concentration of DNA incorporated on MPS and PE. ${ }^{[1,3,10,11]}$

The result of determination of mean particle and DNA entrapment efficiency for each batch is giving in Table 1. The DNA entrapment efficiency of different formulations was in the range of 38.5 to $69.5 \% \mathrm{w} / \mathrm{v}$. DNA entrapment efficiency increases with increasing the albumin concentration in most of the formulations. The entrapment efficiency increases with the increase in DNA: polymer ratio and is highest when the concentration of albumin used is $10 \% \mathrm{w} / \mathrm{v}$. MPS of different formulation was in the range of 8.0 to $21.4 \mu \mathrm{m}$. MPS is increase with increasing the albumin concentration in most of the formulations. The MPS is increases with the increase in DNA: polymer ratio and is highest when the concentration of albumin used is $15 \% \mathrm{w} / \mathrm{v}$. Increase in concentration of albumin from $5-15 \% \mathrm{~W} / \mathrm{V}$ lead to a increase in mean particle size. the effect was found to be significant $(p \leq 0.01)$.

Table 1. Effect of albumin concentration and concentration of DNA incorporated on MPS and PE.

\begin{tabular}{|c|c|c|c|c|c|c|c|c|c|}
\hline \multirow{3}{*}{$\begin{array}{l}\text { Conc. Of Albumin } \\
(\% \mathrm{w} / \mathrm{v})\end{array}$} & \multicolumn{9}{|c|}{ Concentration of DNA Incorporated (\% w/v) } \\
\hline & \multicolumn{3}{|l|}{0.01} & \multicolumn{3}{|l|}{0.02} & \multicolumn{3}{|l|}{0.05} \\
\hline & MPS $(\mu \mathrm{m})$ & OD & PE \% & MPS $(\mu \mathrm{m})$ & OD & PE \% & MPS $(\mu \mathrm{m})$ & OD & PE \% \\
\hline 5 & 8.6 & 0.077 & 38.5 & 8.1 & 0.121 & 60.5 & 8.0 & 0.081 & 40.5 \\
\hline 10 & 15.2 & 0.105 & 52.5 & 12.9 & 0.139 & 69.5 & 12.5 & 0.112 & 56.0 \\
\hline 15 & 21.4 & 0.092 & 46.0 & 20.2 & 0.115 & 57.5 & 19.9 & 0.097 & 48.5 \\
\hline
\end{tabular}

*MPS indicates mean particle size, PE, percentage entrapment.

Increase in concentration of albumin from $5-15 \%$ $\mathrm{W} / \mathrm{V}$ lead to an increase in percentage entrapment. The effect was found to be significant ( $p \leq 0.01)$.

\section{In-vitro dissolution study}

The cumulative amount of DNA (pBR322) released versus time profile for the formulations is shown in Table 2. the formulations contained $0.02 \% \mathrm{v} / \mathrm{v}$ of
DNA. First sampling was done one hour after the formulation was placed on the dissolution apparatus bowel and after 20 hours to evaluate the cumulative $60 \%$ DNA is release. The results showed that the more than $60 \%$ amount of DNA released in the first $20 \mathrm{hr}$.

Table 2. In-vitro drug release study data.

\begin{tabular}{lccc}
\hline $\begin{array}{l}\text { Time } \\
(\mathrm{hr})\end{array}$ & $\begin{array}{l}\text { Amount of DNA release } \\
(\boldsymbol{\mu g} / \mathrm{ml})\end{array}$ & $\begin{array}{c}\text { Percentage release } \\
(\%)\end{array}$ & $\begin{array}{c}\text { Cumulative percentage release } \\
(\%)\end{array}$ \\
\hline 0 & 0 & 0 & 0 \\
20 & 0.7 & 60 & 58.53 \\
40 & 0.77 & 65 & 64.50 \\
60 & 0.89 & 75 & 74.58 \\
80 & 0.95 & 80 & 79.58 \\
100 & 0.98 & 82 & 81.66 \\
\hline
\end{tabular}

The cumulative amount of DNA (pBR322) released versus time profile for the formulations is shown in
Table 2. the formulations contained $0.02 \% \mathrm{v} / \mathrm{v}$ of DNA. First sampling was done one hour after the 
formulation was placed on the dissolution apparatus bowel and after $20 \mathrm{hr}$ to evaluate the cumulative $60 \%$ DNA is release. The results showed that the more than $60 \%$ amount of DNA released in the first $20 \mathrm{hr}$. The initial burst release of the drug from the prepared formulations could be explained by the fact that these systems were formulated in an aqueous vehicle. The matrix formed on gelation was already hydrated and hence hydration and water permeation could no longer limit the drug release. The release of drug decreased significantly as the concentration of polymer increased. The release from various formulations can be ranked at each time point: P1 > P2 > P3 > P4 > P5. This indicates that the structure of gel becomes more tightly packed and functioned as an increasing resistant barrier to drug release, prolonging the release of drug. This was also due to increased viscosity of polymer concentration increased as indicated by the results of viscosity studies. ${ }^{[12,15]}$

\section{CONCLUSION:}

The main objective of the study was to prepare an $E$. coli pBR322 plasmid DNA loaded albumin microsphere which is useful for tumour targeted controlled gene delivery. DNA was successfully loaded in albumin microspheres and in vitro release of DNA was significant. Comparative study shows effect of albumin concentration on mean particle size and DNA entrapment efficiency. As the concentration albumin is increased lead to increase in mean particle size but that pattern do not follow for entrapment efficiency. In the present study entrapment efficiency is found to be dependent on Concentration of albumin and DMA. The DNA entrapment efficiency of different formulation is in the range of 38.5 to $69.5 \% \mathrm{w} / \mathrm{v}$. The formulation of $10 \% \mathrm{w} / \mathrm{v}$ albumin and $0.02 \% \mathrm{w} / \mathrm{v}$ DNA which showed higher entrapment efficiency $(69.5 \% \mathrm{w} / \mathrm{v})$ provides desired DNA release rate. Results suggest that this study can be helpful in the controlled gene delivery. These is cost effective, and controlled DNA delivery system using FDA approved biocompatible or biodegradable and implantable or injectable material could be useful for in vivo gene delivery such as DNA vaccination and gene therapy.

\section{REFERENCES:}

1. Dubey R., Parikh JR., Parikh RR., Effect of heating temperature and time on pharmaceutical characteristics of albumin microsphere containing 5fluorouracil. AAPS Pharmascitech., 4 (1): E4, (2003).

2. Rathod S., Deshpande SG.,. Albumin microspheres as an ocular delivery system for pilocarpine nitrate. Indian J Pharm Sci., 70 (2):193-197, (2008).

3. Sambrook J. Fritsch and Maniatis T, Molecular cloning A laboratory manual, 2nd Edn, Vol-1, Cold Spring Harbor Laboratory Press: 1-40, 1989.

4. Sang Wan Gal. (2 Eds.), Simple DNA Elution from Agarose Gels, Biotechnol. Bioprocess Engineering, 1997, pp. 62-63.

5. Ming Li., Rouaud O., Poncelet D., Microencapsulation by solvent evaporation: State of the art for process engineering approaches. Int J Pharm, 363(1-2): 2639, (2008).

6. Thakkar H., Sharma R., Mishara A., Chuttani K., Albumin Microspheres as Carriers for the Antiarthritic Drug Celecoxi. AAPS pharmSCITech, 6 (1): E65-E73, (2005).

7. Akira It., Honda H., Kobayashi., Liposome for Tumour targeted therapy. Drug Deliv Syst, 17(4): 347-354, (2002).

8. Yu L., Long H., Xiao., Investication of polyDL-Lactideb-poly (ethalene glycol)-b-poly DL-Lactide microsphere containing plasmid DNA. Chinese J Poly Sci, 22(3): 205-214, (2004).

9. Luo D., Saltzman WM., Synthetic DNA delivery systems. Nat Biotechnol, 18(1): 33-37, (1999).

10. Jain D., Panda AK., Eudragit s100 entraped insulin microsphere for oral delivery. AAPS PharmSciTech, 6(1): E100-107, (2005).

11. Pareta R., Edrisinghe MJ., A novel method for the preparation of biodegradable microspheres for protein drug delivery. J Royal Soc Interface, 3(9): 573$582,(2006)$.

12. Hernot S., Klibanov AL., Microbubbles in ultrasoundtriggered drug and gene delivery. Adv Drug Deliv Rev, 60(10): 1153-1166, (2008).

13. Yuan W., Fei W., Guo M., Tuo J., Development of protein delivery microsphere system by a novel S/O/O/W multi-emulsion. Eur J pharm sci,36(2-3): 212-218, (2009).

14. Kratz F., Albumin as a drug carrier: Design of prodrugs, drug conjugates and nanoparticles. J Controlled Release, 132(3): 171-183, (2008).

15. Muller OJ., Hugo A., Bekeredjian R., Targeting the heart with gene therapy-optimized gene delivery methods. Cardiovasc Res, 73(3): 453-462, (2008). 